\title{
The Implementation of Inheritance Dispute Arrangement Based on Local Wisdom in Gayasan A, Jenggawah, Jember Regency
}

\author{
Erfina Fuadatul Khilmi ${ }^{{ }^{*}}$, Arvina Hafidzah ${ }^{2}$, Praptika Septi Femilia ${ }^{3}$ \\ ${ }^{123}$ Institut Agama Islam Negeri Jember, Indonesia \\ Corresponding Author: ${ }^{1 *}$ inabalance07@gmail.com, ${ }^{2}$ arvinahafidz@gmail.com, \\ ${ }^{3}$ praptikaseptifemilia@gmail.com
}

\section{Article}

History:

Submit:

2020-12-09

Publish:

2021-03-05
Differences in understanding the distribution pattern of inheritance rights potentially cause disputes which fade the family relationships and merge endless conflicts among the family members. The aim of the research is to comprehend the implementation of inheritance dispute arrangement based on local wisdom as an alternative method in achieving the community's balance and harmony that they still consider the arrangement through a court action as a taboo of settlement. The research shows several findings; factors that influence the differences in the distribution of inheritance in Gayasan A, Jenggawah, Jember Regency are the absence of communication between the heirs (the giver) and heirs, which is known as debik kek lopaen; and the community's view of the heirs also influence the distribution of inheritance rights, so that local wisdom is needed as a strategic tool in arranging the disputes by implementing internal discussions among the family members mediated by a customary head and a sanction of exclusion (not diajepi). Data collection was conducted through a combination of literature study and field study by triangulating the results of observations, interviews and questionnaires. The research 
design applied was the sociology of law with an approach of problem on the unwritten customary law implemented in the community of Gayasan A as a social fact developed from the value system of the community and supported by a theoretical approach..

Keywords: Local wisdom; Gayasan A Community; Inheritance Dispute

Journal Homepage http://ijssr.net/index.php/ijssr

This is an Open Access article under the CC BY SA license

https://creativecommons.org/licenses/by-sa/4.0/

Published by Indonesian Academy of Social and Religious Research

\section{Introduction}

The development of interactions in a different custom and culture in an area tends to provide a mindset towards attitudes and actions that produce a collective knowledge system in the midst of society, such in the community in Gayasan A, Jenggawah, Jember Regency. The traditions of the Madurese tribe and the community's obedience to the Islamic rules become a factor of how the community behave and act in solving their life problems wisely, one of which is the inheritance distribution system carried out according to pluralism of customary law and Islamic law in an equal position and integrated in the legal system prevailing in society. That is to say, because the system of inheritance distribution usually depends on kinship or individual characteristics of a family. Sometimes it is seen from its role as head of the family, the male party gets more or 2: 1 shares with the woman. However, it cannot be denied that there is a factor of closeness which is one of the influences in the distribution of inheritance which can be shared 1: 1 evenly, as well as women who get more.

This is certainly different from the concept adopted from Hazairin regarding customary inheritance law which has its own character from the traditional minds of the people with the form of patrilineal, matrilineal and bilateral kinship systems. ${ }^{1}$ The difference in understanding the kinship system towards the distribution pattern of inheritance is what is prone to conflicts within a family because the distribution of inheritance rights is not carried out equally. This conflict has caused a split of opinion in kinship, so there is the potential

1 . Yulia, Buku Ajar Hukum Adat, (Lhokseumawe: Unimal Press, 2016), 82. 
for a dispute to occur which will lead to resolution in the litigation path. This settlement action certainly takes a lot of energy, time and money. In addition, the people in Gayasan A seem to see disputes that are resolved in court as taboo and a sign of rift in the kinship of the disputing parties. They consider disputes that have been carried out through mediation, but they are still forced to continue through legal channels, it becomes a form of fading of the disputing parties' sense of kinship which will certainly become a public discussion, this is due to the close kinship between one person and another. ${ }^{2}$

Based on the description above, one of the alternatives used by the Gayasan A community in resolving inheritance disputes is by using local wisdom as an arrangement method that tends to highlight the local characteristics by upholding the principles of morality within a framework of the characteristics of the local community to achieve a balance with the management of inheritance dispute arrangement. This is in line with Suhartini's opinion, which defines local wisdom as a value system of life that is not only in the form of religion, but also culture and customs from generation to generation which are considered to have the wisdom to adapt to the local community environment. ${ }^{3}$

Therefore, the legal issue written in this research is the arrangement of inheritance disputes with a legal pluralism style based on local wisdom as the legal culture of the Gayasan A community and the factors affecting the differences in the distribution of inheritance in the Gayasan A community. It is interesting to be carried out since preservation of local wisdom is an effective means of locality in achieving balance and harmony with regard to dispute arrangement that occurs in the community.

\section{Literature Review}

Studying the legal culture of the community through local wisdom in an area becomes an important aspect in this research when the legal positivism model is not sufficient to solve legal problems in society because written laws are made by authorized officials or stipulated by court judges which often serve as legitimacy to create endless problems. In the context of this study, researchers were more oriented towards the legal culture model of the community in Gayasan A, Jenggawah, Jember Regency in arranging inheritance disputes because the

\footnotetext{
${ }^{2}$ Interview of Mukhtar Hafidz, a member of customary law community in Gayasan A, Jenggawah, Jember.

3 Cited by Agus Wibowo dan Gunawan, Pendidikan Karakter Berbasis Kearifan Lokal, (Yogyakarta: Pustaka Pelajar, 2015), 17.
} 
discussion of inheritance is a sensitive and taboo issue to discuss in family relationships. There are several studies that discuss inheritance that have been carried out previously regarding inheritance disputes in the local area.

First, research conducted by Maria Kaban (2016) entitled Dispute Settlement of Traditional Land Inheritance in Karo Community, this research discusses customary land which is the property of indigenous peoples and if that community member dies, property rights can be inherited to the the heir through the settlement of inheritance disputes over customary land in the Karo community who uses a patrilineal kinship system. The results showed that there were 3 ways taken by the Karo community in resolving inheritance disputes over customary land, first, dispute arrangement through Runggun; second, dispute arrangement through Perumah Begu; third, dispute arrangement through the District Court. The difference from the current research is that this research focuses on the arrangement of inheritance disputes based on local wisdom because it considers that the settlement of legal positivism is not sufficient enough to unite disputing families due to inheritance issues.

Second, a research conducted by Muhammad Taufiq, et al (2016) entitled Implementation of Local Wisdom-Based Civil Dispute Arrangement. This study describes the implementation of civil dispute resolution based on Banyumas local wisdom at the village level. The results of this study indicated that the use of local knowledge that has been accepted by the community is an alternative dispute arrangemnet in the local community of Banyumas Regency who is faced with current legal problems using four stages, namely deliberation to consensus (rembugan), involving moderators, through village institutions if it has not been reached through the deliberation process, the police. The difference from this current research is that it lies in the research locus, where the researchers here take the legal culture of the Gayasan A community, Jenggawah, Jember Regency as the research subject.

Third, research by Evi Oktarina, et al. (2018) entitled the Semendo Community Inheritance System Based on Local Wisdom. The focus of this research is on the Tunggu Tubang inheritance system implemented in the Semendo area and its implementation based on local wisdom. The finding of the research was that the traditional tunggu tubang inheritance system, especially for the tunggu tubing, does not make a Semendo woman special and powerful but as an heir, obliging them to live in the village by providing supervision and family guide towards tunggu tubing as a way to survive the other family members with the 
capital of tunggu tubang assets, so that other family members can be independent. The difference from this current research is that it lies in the legal cultural pattern of inheritance dispute arrangement for the Gayasan A community through a local wisdom approach that tends to share inheritance using several stages such as internal discussion facilities for members, mediation by the hamlet head and customary sanctions.

\section{Research Methods}

From the data, it is shown that the research is a non-doctrinal legal research with qualitative approach. The research aims to describe and identify the unwritten law, namely local knowledge or local wisdom that is built through the value system in the community, so that it is expected to reflect the characteristics of the community concerned on resolving inheritance disputes. It is applied a descriptive research design to answer research problems by describing the facts about the real problem investigated. It is expected that research can obtain a description of the factors that influence differences in the distribution of inheritance of the Gayasan A community and the application of inheritance dispute arrangement based on local wisdom.

The subject of this research is the legal culture behavior of the people of Gayasan A, Jenggawah, Jember Regency. The object of this research lies in local knowledge or local wisdom as an alternative in arranging inheritance disputes with several stages of approach, both internal family, mediation, and even customary sanctions which are the acceptance of local communities in maintaining the harmony and balance among family relationships.

This study uses primary data collection techniques, namely direct and indepth interviews with several members of the Gayasan A community which are intended to obtain correct and accurate information from predetermined sources in helping the research problems related to the facts of the application of local wisdom to the Gayasan A community. In addition, it is also supported by the use of open questionnaire, in which the respondents are given the opportunity to answer freely according to their thoughts regarding the agreement of inheritance disputes arrangement by using the local wisdom approach. By the existence of these data collection instruments, the researchers then carry out a systematic observation by making a categorization first which contains the stages of inheritance dispute arrangement in the community of Gayasan A, Jenggawah, Jember Regency. These research instruments are important in this research to 
communicate what means are used in describing local wisdom as an alternative means of settling inheritance disputes. The research instruments that have been used must be supported by documentation data that comes from books, journals and websites about opinions or theories as a secondary data collection tool that supports primary data using systematic analytical content, then the researchers provide conclusions through a combination between field studies and literature studies

\section{Result and Discussion}

The people of Gayasan A, Jenggawah, Jember Regency have traditionally lived in the east of Mount Jenggawah and are surrounded by rice fields and fields with Madura customs which are thickly integrated with Islamic law. The people in this village, although they are called as "private Madurese" or Madurese who live outside the Madura Island, can still be said to be part of the Madura customary unit itself. In their daily lives, this community has implemented legal pluralism based on Islamic customs and law. In general, legal pluralism is a situation where there are two or more legal systems that are practiced in a social life. ${ }^{4}$ The existence of customary inheritance law pluralism itself is actually influenced by the receptio contorario theory, which is the rebuttal theory of the reciptie theory that explains that Islamic law entered after customary law, therefore Islamic law must follow that local customary law. This Snouck Hugronje and Van Vollenhoven's theory is a rebuttal to Van De Berg's theory, namely the reception in complexu theory, which explains that customary law follows the existence of Islamic law embraced by a customary law community. This reciptie theory aims to make indigenous people not adhere to the teachings of the Islamic religion, because if Islamic teachings are firmly held in a society, it is feared that it would be difficult for the western culture to penetrate the indigenous peoples' lives. ${ }^{5}$ The reciptie theory was clearly denied by customary law experts from Indonesia, namely Prof. Hazairin and Prof. Sayuti Thalib, even Prof. Hazairin called it as the devil's theory because it is so contrast with the 1945 Constitution, as well as with Al-Qur'an and As-Sunnah. ${ }^{6}$

4 Hendra Nurtcahyo, Legal Standing Kesatuan Masyarakat Hukum Adat, (Jakarta: Salemba Humanika, 2010), 15.

5 Cited in Irmawati, “Teori Belah Bambu Syahrizal Abbas: antara Teori Reception in Complexeu, Teori Reciptie, dan Teori Receptio Contrario" Ar Raniry, Vol 2 No 2, (2017), 180.

6 Sovia Hasanah, "Arti Teori eceptio A Contrario" 2018 < www.hukumonline.com > diakses pada tanggal 24 Agustus 2020. 
Yahya Harahap in his book explains the meaning of the reception contorario theory, that customary law must adapt with Islamic law, or precisely existing customary laws must not be contrast with Islamic law adhered by the community. If the prevailing customary law norms are not appropriate or even contrary to their treatment with Islamic law, then the customary law norms must be avoided. ${ }^{7}$ This theory can be said to be a theory that became the beginning of Islamic legal politics in Indonesia. ${ }^{8}$ The concept of the reception contorario theory is in accordance with the MB Hoeker's opinion that there will be rules that set aside one another between both customary law and Islamic law, both apply and create an equal appeal that applies and form a special pattern in the community, although they go hand in hand, it cannot be denied there will still be some conflict. ${ }^{9}$ This reception contarario theory that will influence the inheritance distribution system in Gayasan A, Jenggawah, Jember Regency by integrating Islamic law and customary law, especially regarding inheritance issues in the context of this research.

Dealing with the distribution of inheritance in Gayasan A, it is more directed to a parental or bilateral system (father and mother lineage), namely a system of inheritance distribution that provides equal rights to inherit between male and female parties. ${ }^{10}$ However, in terms of the right of division, the two are not the same; the distribution of inheritance is not only based on the Islamic law, namely 2: 1, but also sometimes applies the 1:1 principle of kinship. ${ }^{11}$ As for the distribution of houses, land, and other immovable assets in this village, there are usually deliberations from the heirs. Sometimes it is the men who get it, but not infrequently the women get the right to the land or house that is inherited.

Several factors affect the differences of inheritance distributions in this village, such as:

1. The existence of good communication between the heirs (the givers) and the heirs (the takers). For example, if someone migrates outside the village then rarely contacts or never contacts at all, the term keluarga

7 Yahya Harahap, Kedudukan Janda, Duda, dan Anak Angkat dalam Hukum Adat, (Bandung: PT. Citra Aditya Bakti, 1993), 62.

8 Adelina Nasution, "Pluralisme Hukum Waris di Indonesia" Al-Qadha 5:1 (2018), 22-23.

9 M.B Houker, Legal Pluralisme: an Introduction to Colonial and Neocolonial Laws, (Offord: University Press, 1975), 25.

${ }^{10}$ Nur Nafa Maulida Atlanta,etc, "Studi Komparasi Hak Waris dalam Hukum Adat dan Islam di Masyarakat Madura Pernatauan Desa Jelbuk, Kecamatan Jelbuk, Kabupaten Jember”,Lentera Hukum Vol.5 Issue 3 (2018), 415.

${ }^{11}$ Soerjono Soekanto, Hukum Adat Indonesia, (Jakarta: PT Raja Grafindo, 2013), 263. 
debik kek lopaen will be used as a reference in reducing the number of inheritance or even for not being given at all. Meanwhile, even though he is an adopted child, if he has a good relationship with the heir (the givers), he may get greater inheritance rights than a biological child.

2. Environmental factors, if the local community feels that it is not appropriate to ask for inheritance rights from their parents, usually seen as having difficulties in terms of assets or having bad behavior in society. Thus, if the child continues to ask, there will be sanctions for exclusion by the community.

3. The nomads who return to their hometowns to take care of the funeral and find themselves getting less or no share at all, make them feel unfair and demand recalculation. ${ }^{12}$

From the three factors above, we can see that the distribution of inheritance emphasizes on the kinship relations rather than 'biological' and 'adopted' status. Emotional relationship is more concerned than looking at the child's status, therefore the customary inheritance law in Gayasan A does not differentiate between the rights of biological and adopted children in terms of inheritance distribution. This is one of the reasons for the debate which eventually led to a dispute between the two parties.

The data shows that $63.8 \%$ random correspondents of 47 people from the community of Gayasan A gave their consent to inheritance disputes that they had observed or even experienced themselves, which is described as follows:

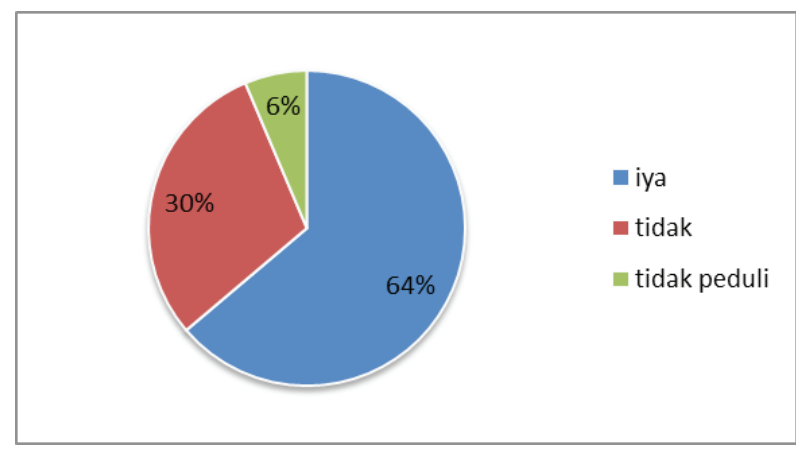

\section{Picture 1. The number of correspondents who had observed or experienced inheritance disputes}

${ }^{12}$ Interview of Mukhtar Hafidz. 
Considering that the matter of inheritance involves the issue of property and family relations which is undeniably a combination of two sensitive things to discuss, so that the dissatisfaction of the parties with the distribution of inheritance requires alternative solutions that characterize the local community by promoting a policy, which is called as local wisdom. Quaritch Wales defines local wisdom or local genius as a collection of cultural characteristics that most people have as a result of their experiences in early life. ${ }^{13}$

There are several ways done by the customary law community in Gayasan A in arranging inheritance disputes according to applicable local wisdom. Namely, the first is through internal discussions between the disputing parties which is usually called as rembugen, then mediation by the customary head, and the last is social sanctions in the form of exclusion (tak diajep) by the local community which is applied to the disputing parties using coercion or violence in the dispute arrangement process.

1. The arrangement of inheritance disputes through internal discussions among the disputing parties (rembugen)

The first way that is usually the initial reference in arranging the inheritance disputes is to have discussions in the family which are sometimes still confidential, often called rembugen. In this discussion, the oldest child or the family member who is considered capable usually leads the way of the discussion in order to get an agreement that is considered fair for all parties. According to one resident, this method is the best way to resolve disputes including inheritance disputes, because the community does not know and cannot spread strange rumors about this inheritance dispute. ${ }^{14}$

Rembugen or internal discussions conducted by the two disputing parties can be seen adhering to three principles in the customary inheritance law stated by Yulia, namely the principle of self-control, the principle of mutual rights, and the principle of kinship, all of which are very important elements in arranging an inheritance dispute. ${ }^{15}$ The principle of self-control is the thought of holding back lust which is usually associated with adherence to the Islamic religion which upholds peace. Then, the principle of mutual rights is the core of this internal discussion, namely the purpose of this discussion is to obtain justice and equality in the distribution of inheritance.

\footnotetext{
${ }^{13}$ Cited in Maria Matildis Banda, "Upaya Kearifan Lokal dalam Menghadapi Tantangan Perubahan Kebudayaan” Fakultas Ilmu Budaya Universitas Udayana, 1.

${ }^{14}$ Observation in Gayasan A, Jenggawah, Jember

${ }^{15}$ Yulia, Op,cit. 86.
} 
Further, the last one is the kinship principle, which means that there is a thought that the dispute occurs within the internal family, so we must look at the factor of kelurge dibik if a further arrangement is needed.

This method is one of the earliest ways of the dispute arrangement process in Gayasan A. The use of internal discussion within the family has its own advantages and disadvantages. One resident who did not wish to be named ${ }^{16}$ said that an internal discussion (rembugen) could be used if both disputing parties were present and participated in the discussion calmly; it means that there was no party that used violence or intimidation. However, it cannot be a last resort for dispute arrangement if one party is constantly trying to voice an opinion without listening to the opinion of the other party, this may even lead to the split of family's opinion whom become a supporter between the two disputing parties. Afterwards, if the arrangement through internal discussions is seemed insufficient or even creates a rift among the family members, the disputing families then need a mediator, in this case, asking the customary head to lead the mediation between the two disputing parties.

2. The arrangement of inheritance disputes mediated by the customary head of Gayasan A, Jenggawah, Jember Regency

If in the family there are still disputes and no agreement has been made regarding the distribution of inheritance, even after conducting the perembugen, then mediation is carried out. Etymologically, mediation comes from the Latin word mediare, which means being in the middle. ${ }^{17}$ This meaning shows a third party who is a mediator or a party that bridges the opinions of two parties with no personal connection with one of them.

The data shows that $53 \%$ of questionnaire correspondents gave approval to the use of mediation as one of the solutions and final solutions in arranging inheritance disputes. Only 25\% of the correspondents stated that mediation was not the last resort or solution in inheritance disputes. Meanwhile 22\% were in doubt, this is because the correspondents never involved in the inheritance disputes or had never experienced inherited disputes. As illustrated below

16 Anonymous informant is needed to give protection to the correspondents

17 Syahrizal Abbas, Mediasi dalam Perspektif Hukum Syariah, Hukum Adat dan Hukum Nasional, (Jakarta: Kencana, 2012), 2. 


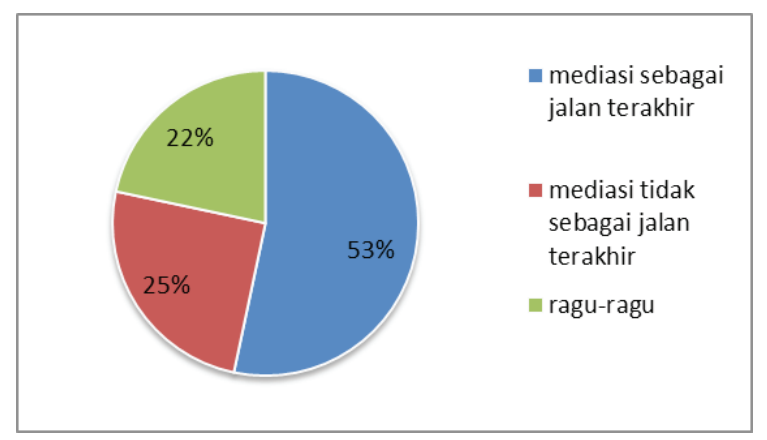

\section{Picture 2. Correspondents' responds about mediation as the last arrangement of inheritance disputes}

Correspondents' respond regarding mediation in the arrangement of inheritance disputes shows the power of mediation as stated by Christopher W. Moore, "if the power of influence potencials of equal in strength, and recognized by all disputants, the mediator's job will $n$ be the assist the disputants in using their influence effectively to oroduce mutually sastisfactory results"18. Moore has clearly given his opinion regarding the strength of the parties in the mediation of inheritance disputes which if it is developed properly and includes strong positive influence of the mediator, it will provide a result of decisions that can be agreed upon by all parties (win-win solution). In addition the strengths of moral, legal, political and social of the parties in the mediation, the confidentiality that is maintained by the mediator is one of the reasons for making mediation a step towards resolving disputes without having to announce it to the public as happens if it passes through the court.

Regarding the mechanism of mediation arrangement in Gayasan A, Jenggawah, it is carried out by the customary head as a mediator in providing solutions. According to the results of a questionnaire collected from the customary law community in Gayasan A, 38.39\% of correspondents said that the mediation was not carried out by the customary head but by other mediators such as religious leaders, village heads and community leaders. The customary head sometimes delegates his power to other mediators due to other activities that must be taken care of by him. However, it cannot be denied that the role of the customary head as a mediator is one form of

18 Cited by H.Ahmad, "Eksistensi dan Kekuatan Mediasi dalam Penyelesaian Sengketa Perdata di Pengadilan” istinbath' Jurnal hukum islam (2014), 78. 
preserving local wisdom that has existed for a long time and is still used by the customary law community in Gayasan A, Jenggawah, Jember Regency. ${ }^{19}$

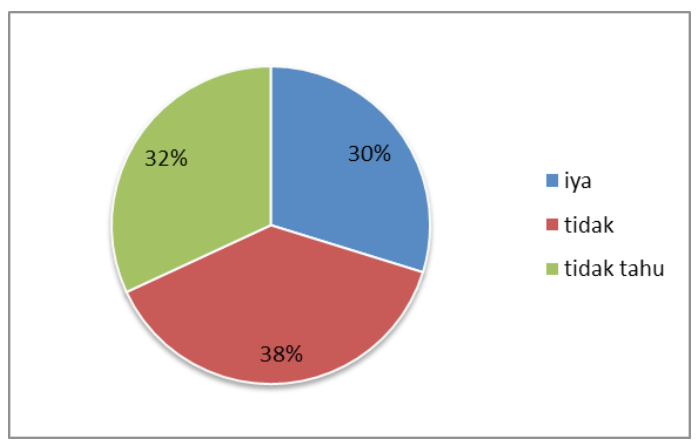

\section{Picture 3. Correspondents' statement regarding the existence of customary head in the arrangement of inheritance disputes}

Mediation of inheritance disputes is followed by both disputing parties and must be followed by at least half the kinship members who know directly the issue of inheritance disputes. Apart from being witnesses, their existence is also a safeguard if there is something they do not want, such as an element of violence or intimidation by one party who is deemed unethical in conducting mediation. If only the two parties join the mediation because they don't want to be known by other relatives or even the community, the customary head as the mediator allows it. This is where religious figures that have influence in this village enter as witnesses and guards if something unwanted happens. The selection of religious figures as witnesses to participate is a mutual agreement between the mediator and the disputing parties, considering that religious leaders, apart from understanding inheritance, are also wise and have good temperaments so that they are suitable to reduce tension between the disputing parties when conducting mediation.

After everyone is present, the Mediator invites one party to explain the situation according to its own point of view. When expressing an opinion, no party should intervene and even intimidate him until he has finished talking and so are the other parties. Then after listening to the story and sitting down the case from the perspective of the two disputing parties, the village head will discuss together with relatives or religious leaders in

19 Questionnaire by correspondents 
determining a solution that will be offered later. The solution offered by the mediator after discussing it with relatives or religious leaders really depends on the circumstances of the disputing parties. If the two of them continue to insist on their will, the solution offered is that the disputed inheritance will usually be divided into two between them or if one party gives in because they do not want the fight to continue, the customary chief allows it. ${ }^{20}$

3. Exclusion sanction (tak diajepi) by the customary law community of Gayasan A, Jenggawah against those who enforce inheritance rights

Disputes between the two parties, especially in sensitive matters such as the matter of inheritance, are considered taboo. This is due to the assumption by the local community that the disputing families will become disharmonious even after the dispute is over. The customary law community who lives in Gayasan A strongly adheres to the principle of kinship which often results in customary sanctions in the form of exclusion or is often called tak diajepi of the disputing family, especially to one of the parties considered to be intimidating or coercive in the inheritance dispute.

The implementation of this sanction has indirectly become a local wisdom upheld by the customary law community of Gayasan A. The visible effect is quite good, because the local community does not want to be considered a stranger; the disputing parties finally decide to make peace. This is in line with the opinion expressed by Hovland, Janis, and Kelly, that the desire to remain part of the group is the basic motivation for a person to have legal compliance. ${ }^{21}$ In view of this opinion, the law of exclusion (tak diajepi) on the party who enforces the inheritance dispute becomes something that can impact on the individual's social process. Therefore, it can be considered that this sanction has a fairly good punitive effect in this case.

The form of exclusion (tak diajepi) carried out by the customary law community of Gayasan A, Jenggawah, Jember Regency is usually in the form of community's reluctance to associate with persons or families who are sanctioned. Simple things such as not including the wives of the disputing parties in rumpi or small talking carried out by the wives of the area, which are usually done when sorting tobacco leaves for sale, considering tobacco

20 Observation through cases of inheritance disputes in Gayasan A, Jenggawah, Jember

21 Soerjono Soekanto, Op.cit, 327. 
as one of the local varieties driving forces for the economy of Jember community. In addition, it can be in the form of not inviting the party into the customary tradition selasaan which is routinely carried out every week at the house of one of the residents. The last is a form of exclusion accompanied by rumors and gossip.

It should be understood that the people living in Gayasan A, Jenggawah, Jember Regency have a strong tie between one individual and another. Therefore, this exclusion sentence can be a 'shame' for the individual who is sentenced. Especially in spreading rumors and gossip, individuals who are gossiped about will usually be more introspective and pay attention to their behavior, often even apologizing and showing their peace to the customary law community in Gayasan A. Evidence of peace is usually seen from how the two disputing parties appear to be chatting together, greet each other and there is no longer any tendency or tension between the two.

Considering the effects, this is in accordance with Mowrer's assumption, "if one identified with a force of which is afraid, one can no longer be hurt by it" 22 that the imposition of a punishment against someone can be a common thing in life of that individual, because it means a society gives a continuous effect on the individual who is sentenced to live in accordance with the social order. This is of course very risky turning into a social intimidation which causes one of the excluded individuals to feel that it is no longer appropriate to live in a community or to feel uncomfortable with the surrounding conditions so that they choose to leave the village or move, but once again it rarely happens in this village because of their intimacy between the customary law community.

\section{Conclusion}

The conclusion that we can draw from the discussion above is that the distribution of inheritance in Gayasan A is inseparable from the application of a legal pluralism system that places Madurese customary law which in fact is the origin of most of the people in Gayasan A, Jenggawah, Jember Regency and Islamic law as their religion. However, sometimes when dealing with the distribution of inheritance, disputes occur which of course breaks the relationship between the two disputing parties. This is mainly due to the existence of a system of close relations with the heir that could cross the boundaries of the status of

22 Ibid, 329. 
biological and adopted children, or the heir's disagreement with the heir's (the giver's) decision which is based on the opinion of the customary law community. The existence of local wisdom as a strategic alternative means for arranging inheritance disputes in Gayasan A, Jenggawah, Jember Regency, is implemented through several concerns, as follows: First, internal family discussions (perembugen) which are usually led by the oldest child or a neutral family party of inheritance disputes. Second, mediation by the customary head as the appointed mediator,but because of other busy that must be taken care of by the head of adat Gayasan A A village, in its implementation, mediation is not carried out by the head of adat but using other mediators such as religious leaders, village heads and community leaders Third, customary sanctions in the form of exclusion (tak diajepi) against perpetrators who commit violations, besides sometimes rumors or gossips also usually spread about a party seems to have violated the customs of the customary law community in Gayasan A, Jenggawah, Jember Regency. The existence of this customary sanction is solely so that the perpetrator gets a lesson effect and apologizes, then makes peace with his family and is able to return to the structure of community as a better individual.

\section{Acknowledgement}

This paper would not have been created without the help of all those who belong to the indigenous community group of Gayasan A, Jenggawah, Jember Regency who have been willing to conduct interviews or to fill out the questionnaires that have been provided. Further, it is conveyed thank you very much to the Head of Customs and Religious Figures who are willing to provide information about the arrangement of inheritance disputes in Gayasan A, Jenggawah, Jember Regency. This paper will never be finished if there is no cooperation from all parties who have been participating and providing the information.

\section{Reference}

Abbas, Syahrizal. Mediasi dalam Perspektif Hukum Syariah, Hukum Adat dan Hukum Nasional. Jakarta: Kencana, 2012.

Ahmad. H. "Eksistensi dan Kekuatan Mediasi dalam Penyelesaian Sengketa Perdata di Pengadilan" istinbath' Jurnal hukum islam (2014). 
Atlanta, Nur Nafa Maulida dkk, "Studi Komparasi Hak Waris dalam Hukum Adat dan Islam di Masyarakat Madura Pernatauan Desa Jelbuk, Kecamatan Jelbuk, Kabupaten Jember” Lentera Hukum Vol.5 Issue 3 (2018)

Banda, Maria Matildis. "Upaya Kearifan Lokal dalam Menghadapi Tantangan Perubahan Kebudayaan" Fakultas Ilmu Budaya Universitas Udayana.

Harahap, Yahya. Kedudukan Janda, Duda, dan Anak Angkat dalam Hukum Adat. Bandung: PT. Citra Aditya Bakti, 1993.

Hasanah, Sovia. "Arti Teori eceptio A Contrario" 2018 www.hukumonline.com diakses pada tanggal 24 Agustus 2020.

Houker, M.B. Legal Pluralisme: an Introduction to Colonial and Neocolonial Laws. Offord: University Press, 1975.

Irmawati. "Teori Belah Bambu Syahrizal Abbas: antara Teori Reception in Complexeu, Teori Reciptie, dan Teori Receptio Contrario" Ar Raniry, Vol 2 No 2, (2017)

Nasution, Adelina. "Pluralisme Hukum Waris di Indonesia". Al-Qadha 5:1 (2018)

Nurtcahyo, Hendra. Legal Standing Kesatuan Masyarakat Hukum Adat. Jakarta: Salemba Humanika, 2010.

Soekanto, Soerjono. Hukum Adat Indonesia. Jakarta: PT Raja Grafindo, 2013.

Yulia. Buku Ajar Hukum Adat. Lhokseumawe: Unimal Press, 2016.

Wibowo, Agus \& Gunawan. Pendidikan Karakter Berbasis Kearifan Lokal. Yogyakarta: Pustaka Pelajar, 2015. 